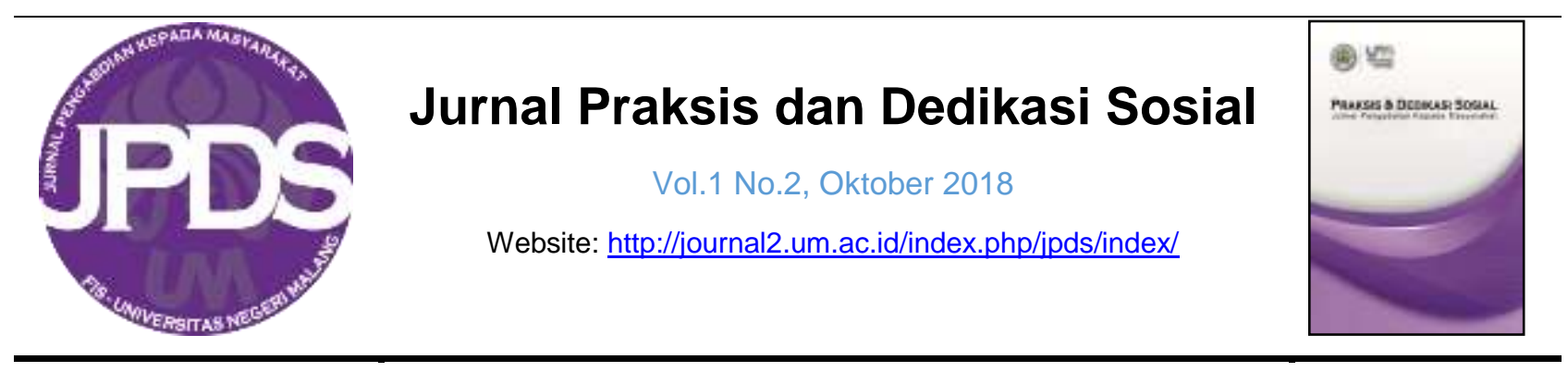

\title{
PELATIHAN DAN PENDAMPINGAN PEMBUATAN RANCANGAN USAHA (BUSSINESS PLAM) PADA SISWA SMK NUSANTARA TANGERANG SELATAN
}

\author{
Sufyati H.S. ${ }^{1}$, Dipateruna Awaludin ${ }^{2}$ \\ ${ }^{1}$ Prodi Manajemen, ${ }^{2}$ Prodi Akuntansi, Fakultas Ekonomi, Universitas Nasional. \\ Diterima 22 Juni 2018, dipublikasikan 31 Oktober 2018.
}

\begin{abstract}
Abstrak
Pendidikan kewirausahaan merupakan salah satu program pemerintah khususnya Kementerian Pendidikan Nasional/Kemendiknas yang bertujuan untuk membangun dan mengembangkan manusia yang berjiwa kreatif, inovatif, sportif dan wirausaha. Tujuan pelaksanaan pengabdian masyarakat ini adalah untuk menghasilkan tamatan Sekolah Menengah Kejuruan/SMK yang siap untuk bersaing dalam dunia wirausaha. Mengembangkan SMK menjadi tempat pembiasaan penerapan karakteristik wirausaha. Pelaksanaan kegiatan pengabdian kepada masyarakat dilakukan di SMK Nusantara Pisangan Ciputat Timur Tangerang Selatan. Peserta yang mengikuti kegiatan ini berjumlah 50 siswa kelas 3 (tiga). Metode kegiatan yang dilakukan meliputi beberapa tahapan dan langkah yaitu: 1) Persiapan, 2) Penyuluhan Kewirausahaan, 3) Pelatihan dan pendampingan pembuatan rancangan usaha (bussiness plan), dan ke 4) Evaluasi. Hasil kegiatan menunjukkan bahwa pelatihan dan pendampingan berdasarkan hasil monitoring dan evaluasi dalam upaya membangun jiwa wirausaha para siswa SMK dapat terlaksana dengan baik dan mendapat respon positif dari para siswa dan sekolah. Pelaksanaan kegiatan pengabdian masyarakat ini sangat bermanfaat bagi siswa sebagai persiapan bersaing dalam kancah di pasar tenaga kerja dan kemandirian usaha. Perlunya adanya kelanjutan pendampingan untuk mencoba membuka unit usaha kecil yang dikelola oleh para siswa sebagai inkubator bisnis di sekolah tersebut dan sebagai wadah pelatihan wirausaha.
\end{abstract}

\section{Kata Kunci}

Pelatihan, Pendampingan, Kewirausahaan, Bussiness Plan

(C) 2018 Penulis

\section{PENDAHULUAN}

Keunggulan suatu bangsa terkait dengan kemampuan daya saingnya dengan bangsabangsa lain. Untuk dapat berkompetisi tentu diperlukan keunggulan-keunggulan, baik keunggulan kompetitif (kemampuan SDM) dan komparatif (terkait dengan sumber daya

\footnotetext{
${ }^{1}$ Surel Korespondensi: sufyati.hs@civitas.unas.ac.id
}

alam yang tersedia). Daya saing mengacu pada kemampuan bersaing seseorang, kelompok, masyarakat atau bangsa terhadap individu, atau bangsa lain yang berkaitan dengan nilai berkompetisi terhadap pesaingnya.

Upaya Pemerintah dalam menyempurnakan sistem pendidikan antara lain dapat dilihat dari disahkannya UU No: 20 Jurnal Praksis dan Dedikasi Sosial Vol.1 No.2 2018 p.87-94 | 87 
Pelatihan dan Pendampingan Pembuatan Rancangan Usaha...

tahun 2003 tentang SISDIKNAS dan PP No. 19 tahun 2005 tentang Standar Nasional Pendidikan telah memberikan banyak ruang bagi lembaga pendidikan untuk membuat dan mengelola kurikulumnya sesuai dengan tensi dan kompentensi wilayah/ lingkungan yang dimilikinya. Hal ini berkaitan erat dengan kurikulum yang disusun di sekolah guna menjawab masalah peningkatan kualitas sumber daya manusia melalui kurikulum berbasis wirausaha. Pendidikan berbasis kewirausahaan adalah proses pembelajaran penanaman tata nilai kewirausahaan melalui pembiasaan dan pemeliharaan perilaku dan sikap.

Pendidikan kewirausahaan merupakan salah satu program pemerintah khususnya Kementerian Pendidikan Nasional/ Kemendiknas yang bertujuan untuk membangun dan mengembangkan manusia yang berjiwa kreatif, inovati, sportif dan wirausaha. Program pendidikan kewirausahaan ini dikaitkan dan diintegrasikan dengan program-program lain, seperti pendidikan karakter, pendidikan ekonomi kreatif dan pendidikan kewirausahaan ke dalam kurikulum sekolah. Untuk membangun semangat kewirausahaan dan memperbanyak wirausahawan, Pemerintah telah mengeluarkan Instruksi Presiden Nomor 4 Tahun 1995 tentang Gerakan Nasional Memasyarakatkan dan Membudayakan Kewirausahaan. Instruksi ini mengamanatkan kepada seluruh masyarakat dan bangsa Indonesia untuk mengembangkan program-program kewirausahaan (Intruksi Presiden Republik Indonesia, 1995).
Kewirausahaan adalah proses dinamik untuk menciptakan tambahan kemakmuran (Alma, B., 2011). Istilah kewirausahaan berasal dari terjemahan "Entrepreneurship", Menurut Thomas W. Zimmerer, Kewirausahaan merupakan gabungan dari kreativitas, inovasi dan keberanian menghadapi resiko yang dilakukan dengan cara kerja keras untuk membentuk usaha baru. Kata wirausaha atau pengusaha diambil dari bahasa Perancis "entrepreneur" yang pada mulanya berarti pemimpin musik atau pertunjukan (Jhingan, 1999). Istilah Wirausaha sering dipakai tumpang tindih dengan istilah Wiraswasta. Ada pandangan yang menyatakan Wiraswasta sebagai pengganti dari entrepreneur sedangkan Wirausaha sebagai pengganti dari entrepreneurship (Sumahamijya, S., 1981).

Sekolah atau pendidikan menjadi tempat yang sangat strategis untuk menumbuhkan bakat wirausaha. Beberapa alasan sekolah formal dapat menumbuhkan bakat wirausaha, yaitu: Pertama, sekolah adalah lembaga pendidikan yang sangat dipercaya masyarakat untuk masa depan yang lebih baik. Kedua, jaringan sudah ada di seluruh pelosok negeri. Ketiga, melalui sekolah juga bisa menjangkau dan mempengaruhi keluarga anak didik (Nugroho, R., 2009).

Sekolah Menengah Kejuruan/SMK merupakan sekolah formal di bawah Departemen Pendidikan nasional, mempunyai tujuan antara lain adalah menghasilkan lulusan yang siap memasuki lapangan kerja secara mandiri sebagai wirausaha (entrepreneur). Usia siswa yang rata-rata masih dalam masa yang 
produktif untuk menerima ilmu pengetahuan dan teknologi termasuk di dalamnya ilmu wirausaha, maka SMK menjadi sangat penting dalam menyiapkan tamatan yang siap berwirausaha.

Untuk itu, karakteristik wirausaha di SMK perlu dikondisikan baik melalui jalur kegiatan intrakurikuler, kokurikuler maupun ekstrakurikuler, sehingga diharapkan dengan kondisi lingkungan yang menerapkan karakteristik wirausaha, siswa menjadi terbiasa untuk menerapkannya dan pada akhirnya akan menjadi karakter kepribadian siswa yang mandiri.

Kegiatan pengabdian kepada masyarakat merupakan salah satu wujud Tri Dharma Perguruan Tinggi selain pengajaran dan penelitian. Kegiatan pengabdian kepada Masyarakat yang akan dilakukan meliputi pemberian pelatihan dan pendampingan kewirausahaan, yaitu pembuatan rancangan usaha (bussines plan). Salah satu kunci sukses memulai usaha adalah membuat sebuah perencanaan usaha/ bisnis yang matang dan realistis. Business Plan merupakan suatu dokumen yang menyatakan keyakinan akan kemampuan sebuah bisnis untuk menjual barang atau jasa dengan menghasilkan keuntungan yang memuaskan dan menarik bagi penyandang dana.

Business

Plan sebuah selling document yang mengungkapkan daya tarik dan harapan sebuah bisnis kepada penyandang dana potensial. HisrichPetters memberikan definisi sebagai berikut business plan merupakan dokumen yang disiapkan oleh wirausaha yang menggambarkan semua unsur-unsur yang relevan baik internal maupun eksternal mengenai perusahaan untuk memulai suatu usaha (Denawanto, 2018). Rencana usaha sangat berguna untuk mengidentifikasi kebutuhan konsumen, atribut produk yang paling diinginkan dan memastikan rencana perusahaan di berbagai aspek, seperti produksi, distribusi, penentuan harga, dan pemasaran (Yohana 2015). Aspek klasik dari program pendidikan kewirausahaan adalah pelatihan tentang rencana usaha (Fregetto, 2005). Alasannya adalah rencana usaha merupakan kebutuhan setiap pengusaha. Rencana usaha seharusnya sangat berguna bagi pengusaha, tetapi kebanyakan pengusaha tidak mempersiapkannya, padahal rencana usaha umumnya diasumsikan mengarah pada kesuksesan dalam berwirausaha.

Kelompok sasaran dalam pengabdian masyarakat ini adalah siswa Kelas 3 (tiga) SMK Nusantara Pisangan Ciputat Timur Tangerang Selatan. Siswa Kelas tiga sebagai sasaran dimaksudkan untuk mempersiapkan lulusan yang dapat berdaya saing di kancah pasar tenaga kerja siap pakai dan diharapkan mampu menciptakan kemandirian usaha dengan mendirikan unit usaha kecil sehingga dapat menyerap tenaga kerja baru.

Adapun tujuan dilakukan kegiatan pengabdian kepada masyarakat kepada siswa SMK ini adalah agar: 1) Menghasilkan tamatan Sekolah Menengah Kejuruan dapat bersaing dan siap pakai di pasar tenaga kerja; 2) Menghasilkan tamatan Sekolah Menengah Kejuruan yang dapat menciptakan lapangan pekerjaan melalui pendirian unit usaha kecil dan kemandirian usaha; 3) 
Pelatihan dan Pendampingan Pembuatan Rancangan Usaha...

Mengembangkan Sekolah Menengah

Kejuruan yang dapat menjadi tempat pembiasaan penerapan karakteristik wirausaha yang mandiri.

\section{METODE}

Pelaksanaan kegiatan pengabdian kepada masyarakat dilakukan di SMK Nusantara Pisangan Ciputat Timur Tangerang Selatan. Peserta yang mengikuti pelatihan kewirausahaan sebanyak kurang lebih 50 siswa kelas 3 (tiga) dan dilaksanakan selama 2 (dua) hari pada tanggal 28 dan 29 Agustus 2018. Metode kegiatan yang dilakukan meliputi beberapa tahapan dan langkah-langkah yaitu: 1) Persiapan, 2) Penyuluhan Kewirausahaan, 3) Pelatihan dan pendampingan pembuatan rancangan usaha (bussiness plan), dan ke 4) Evaluasi. Metode kegiatan ini digambarkan pada gambar 1.

\section{HASIL DAN PEMBAHASAN}

Hasil dari kegiatan pengabdian pada masyarakat ini akan dikemas dalam bentuk beberapa tahapan kegiatan dan pelaksanaan yaitu persiapan, penyuluhan, pelatihan dan pendampingan. Dalam pengabdian masyarakat ini jumlah siswa yang hadir kurang lebih 50 siswa. Kegiatan ini berlangsung selama dua hari, pelaksanaan kegiatan menyesuaikan waktu belajar siswa, mengingat siswa yang dipilih adalah siswa kelas 3(tiga), yang sedang mempersiapkan ujian nasional. Materi kegiatan diberikan oleh 2(dua) orang dosen dan 2(dua) orang mahasiswa sebagai tenaga perbantuan, serta 2(dua) orang guru SMK sebagai pendamping.

\section{Tahap Persiapan}

Melakukan penjajakan terhadap pelaksanaan kegiatan penyuluhan kewirausahaan ini pada sasaran siswa kelas 3(tiga) SMK Nusantara Tangerang Selatan. Selanjutnya hasil penjajakan dipergunakan untuk penyusunan materi kegiatan, jadwal kegiatan dan tempat yang akan digunakan untuk pelaksanaan kegiatan. Peralatan sebagai penunjang kegiatan pelatihan meliputi white boord, LCD, laptop,alat tulis dan lainnya.

Upaya untuk menumbuh kembangkan jiwa kewirausahaan ini dilakukan karena semakin maju suatu negara semakin banyak orang yang terdidik dan banyak pula orang menganggur, maka semakin dirasakan pentingnya dunia wirausaha. Pembangunan akan lebih berhasil jika ditunjang oleh wirausahawan yang dapat membuka lapangan kerja karena kemampuan

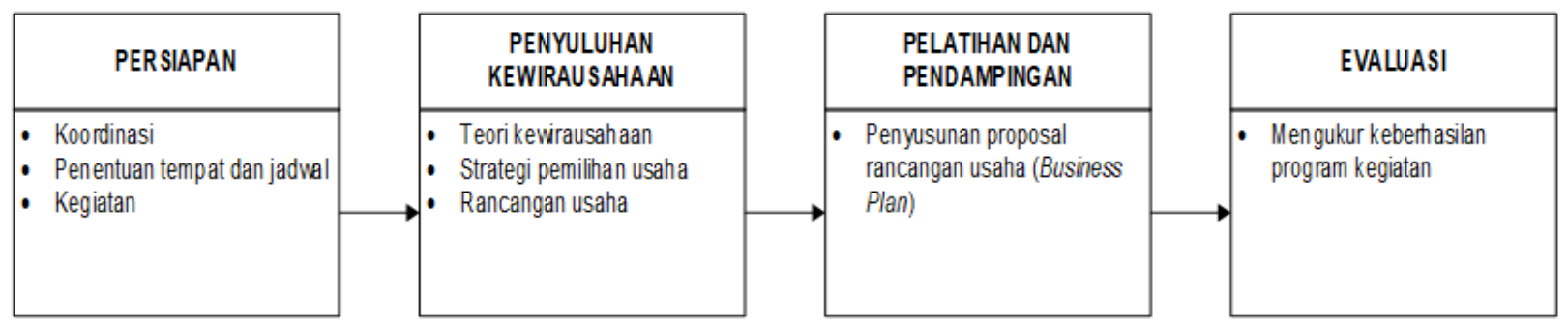

Gambar 1. Metode Pelaksanaan Kegiatan 
pemerintah sangat terbatas. Pemerintah tidak akan mampu menggarap semua aspek pembangunan karena sangat banyak membutuhkan anggaran belanja, personalia, dan pengawasan. Sedangkan karakter dan jiwa wirausaha dipengaruhi oleh pengetahuan, keterampilan, kemampuan, atau kompetensi. Orientasi pendidikan kewirausahaan memiliki jiwa dan pengetahuan ekonomi tertentu untuk diciptakan dan berinovasi. Untuk menciptakan suatu usaha diperlukan perencanaan yang tepat dan terperinci karena perencanaan usaha merupakan alat untuk memastikan bahwa sebuah usaha dijalankan dengan benar dan tepat, yang mencakup pemilihan kegiatan yang akan dijalankan, bagaimana menjalankan, dan halhal lain untuk membantu tercapainya tujuan usaha.

\section{Tahap Penyuluhan Kewirausahaan}

Materi penyuluhan kewirausahaan yang telah disusun oleh penulis meliputi: 1. Teori Kewirausahaan 2. Strategi pemilihan usaha, 3. Rancangan usaha (bussiness plan). Teknik dan metode yang digunakan yaitu ceramah dan diskusi. Dalam tahapan ini materi yang disampaikan adalah materi teori dasar-dasar kewirausahaan, meliputi menumbuhkan minat, ide, bakat, kreativitas, motivasi dan inovasi berwirausaha. Selanjutnya pengenalan bentuk kegiatan wirausaha dikelola sendiri, dikelola orang lain, patungan, dikelola sendiri artinya pengusaha memiliki modal uang dan kemampuan langsung terjun mengelola usahanya. Dikelola orang lain artinya pengusaha cukup menyetor sejumlah uang dan pengelolaan usahanya diserahkan kepada pihak lain.

Wirausaha dapat dijalankan seorang atau sekelompok orang. Jenis usaha yang dijalankan dapat bersifat komersial dan sosial atau kedua-duanya, memiliki modal sekaligus menjadi pengelola; menyetor modal dan pengelolaan ditangani oleh pihak mitra;ataupun dalam bentuk saham sebagai bukti kepemilikan. Materi berikutnya yaitu rancangan usaha (bussiness plan). Perencanaan usaha merupakan langkah pertama dalam berwirausaha untuk mengantisipasi faktor-faktor yang menyebabkan kegagalan untuk menghadapi setiap tantangan dalam menjalankan usaha. Rencana usaha tampaknya menyiratkan bahwa kesuksesan dalam berwirausaha diasumsikan lebih banyak dari pada apa yang pengusaha lakukan. Aspek klasik dari program pendidikan kewirausahaan adalah pelatihan tentang rencana usaha (Fregetto, 2005). Alasannya adalah rencana usaha merupakan kebutuhan setiap pengusaha. Rencana usaha seharusnya sangat berguna bagi pengusaha, tetapi kebanyakan pengusaha tidak mempersiapkannya, padahal rencana usaha umumnya diasumsikan mengarah pada kesuksesan dalam berwirausaha.Rancangan usaha ini berisikan latar belakang pendirian usaha, tujuan, visi dan misi usaha.Rancangan produksi/operasional, biaya kebutuhan modal kerja, SDM yang mengerjakan wirausaha, strategi memasarkan produk, lokasi usaha, segmen pasar (wanita/ laki-laki, dewasa/ remaja/ anak). 


\section{Tahap Pelatihan dan Pendampingan Penyusunan Bussiness Plan.}

Sebelum tahapan ini dimulai, maka seluruh siswa dibagi menjadi beberapa kelompok yaitu satu kelompok terdiri dari 5(lima) dengan tujuan untuk memudahkan mereka membuat proposal rancangan usaha (bussiness plan) dengan membagi tugas masing-masing sesuai dengan point-point dalam rancangan usaha tersebut. Adapun dasar pembagian kelompok adalah pilihan usaha yang akan dilakukan oleh para peserta apabila mereka akan membuka usaha sendiri. Setelah masing-masing kelompok terbentuk, setiap peserta mendiskusikan satu jenis usaha yang akan mereka bangun, kemudian secara bersama-sama membuat perencanaan usahanya. Tim pelaksana memberikan arahan dan bantuan kepada masing-masing kelompok.

Dalam tahapan pelatihan ini terdiri dari soft skills dan pembuatan rancangan usaha.Tujuan dari kegiatan ini adalah agar para siswa dapat berpikir kreatif dan inovatif dalam menyusun rancangan usaha dengan strategi wirausaha yang tepat guna sesuai dengan minat dan kemampuan.Kegiatan pelatihan kemudian dilanjutkan dengan kegiatan pendampingan. Kegiatan pendampingan disertai dengan kegiatan monitoring dan evaluasi. Tujuannya adalah untuk mengetahui kemampuan peserta dalam menyerap materi pelatihan, kendala dan permasalahan yang dihadapi serta mencari solusi dari permasalahan tersebut agar pengabdian dapat berjalan secara berkelanjutan sampai siswa dapat menyelesaikan secara mandiri.
Penyampaian materi pelatihan digunakan dengan beberapa metode yang relevan, antara lain metode ceramah dan permainan (games). Materi yang diberikan meliputi materi Wirausaha dan Perencanaan Usaha, Penyusunan Rencana Usaha, dan Contoh Perencanaan Usaha, masing-masing disampaikan selama 20 menit, diskusi dan tanya jawab sebanyak 1 sesi selama 30 menit, serta praktik penyusunan perencanaan usaha selama 60 menit, dilanjutkan presentasi oleh peserta selama 30 menit. Metode ceramah dan permainan digunakan untuk memaparkan materi yang telah disusun oleh tim pelaksana. Disertai dengan games yang ditujukan untuk mengetahui bidang usaha apa yang kelak akan ditekuni sesuai dengan bakat dan kegemaran. Metode diskusi dan tanya jawab digunakan untuk merespon sejauh mana tingkat pemahaman peserta pelatihan tentang bahan/materi yang telah disampaikan oleh tim pelaksana. Metode presentasi dilakukan oleh peserta, yaitu siswa diminta untuk praktik membuat perencanaan usaha dengan bimbingan dari tim pelaksana. Kemudian mereka memaparkan hasil rancangan usaha yang telah disusun, dilanjutkan dengan sesi tanya jawab dari peserta dan tim pelaksana mengenai perencanaan usaha yang mereka buat. Di akhir pelatihan diberikan post-test sebagai bahan evaluasi untuk melihat sejauh mana pemahaman siswa dalam menyerap ilmu yang diberikan. Rancangan evaluasi dilakukan dalam dua tahap. Pertama, tes (pre test dan post test) dalam bentuk pemberian kuesioner berupa pertanyaan tentang tingkat 
pemahaman peserta mengenai pengetahuan kewirausahaan dan perencanaan usaha. Pertanyaan itu diajukan pada saat sebelum dan setelah pelatihan dimulai.

\section{Evaluasi}

Dengan adanya pelatihan penyusunan perencanaan usaha ini, peserta dan seluruh siswa diharapkan dapat menjadi panutan dalam membuka usaha sendiri sesuai dengan perencanaan usaha yang telah disusun, membangun usaha yang penuh inovasi baru secara kreatif sehingga dapat meningkatkan kualitas hidup, mengurangi pengangguran, serta mendukung majunya perekonomian. Kepada tim pelaksana, secara umum diharapkan dapat melanjutkan kembali kegiatan pengabdian ini dengan terjun secara langsung untuk membina para siswa yang memiliki semangat serta motivasi untuk membuka usaha sendiri/berwirausaha. Secara khusus diperlukan pelatihan lanjutan mengenai pembuatan/penyusunan analisis keuangan dalam rangka mendukung pembuatan perencanaan usaha dan pengembangan usaha. Evaluasi terhadap pelaksanaan kegiatan ini dilakukan baik terhadap proses maupun hasil yang didasarkan pada beberapa aspek, yaitu : a. Kehadiran peserta b. Respon dan Keaktifan peserta c. Motivasi dan Minat peserta d) Tanggung jawab peserta.Target rencana jumlah siswa yang akan mengikuti pelatihan

Tabel 1. Data Peserta Pelatihan

\begin{tabular}{cc}
\hline Jenis Kelamin & Jumlah Siswa \\
\hline Putera & 28 \\
Puteri & 19 \\
Jumlah & $\mathbf{4 7}$ \\
\hline
\end{tabular}

berjumlah 50 siswa, namun realisasi yang hadir berjumlah 47 siswa dengan klasifikasi putera 28 dan 19 putri.

\section{KESIMPULAN}

Berdasarkan pembahasan yang telah dipaparkan tersebut di atas terlihat bahwa setelah diberikan pelatihan penyusunan perencanaan usaha, wawasan para siswa peserta bertambah. Peserta lebih memahami tujuan dan manfaat menyusun perencanaan usaha serta pentingnya membuat perencanaan usaha sebagai langkah awal dalam berwirausaha. Berdasarkan hasil pelaksanaan kegiatan pelatihan yang telah dilakukan, dapat ditarik simpulan sebagai berikut. Pengetahuan peserta mengenai kewirausahaan tergolong sangat kuat yang terlihat dari hasil pre-test dan post-test. Hasil ini cukup membanggakan karena sebagian besar peserta adalah peserta yang telah mendapatkan pelajaran kewirausahaan dari sekolah pada tahun sebelumnya. Penyampaian pengetahuan tentang penyusunan perencanaan usaha dapat meningkatkan pengetahuan dan pemahaman siswa mengenai tujuan dan manfaatnya serta pentingnya membuat perencanaan usaha sebelum memutuskan berwirausaha. Hal ini terlihat dari hasil post-test yang menunjukkan peningkatan yang signifikan. Secara umum peserta sudah cukup memahami bagaimana cara membuat perencanaan usaha. Namun, berdasarkan aspek pembuatan perencanaan usaha, yakni profil perusahaan, analisis pasar, organisasi dan analisis keuangan terlihat bahwa pemahaman peserta masih sangat kurang untuk aspek analisis keuangan. Dengan adanya pelatihan 
Pelatihan dan Pendampingan Pembuatan Rancangan Usaha...

penyusunan perencanaan usaha ini, siswa diharapkan dapat menjadi panutan dalam membuka usaha sendiri sesuai dengan perencanaan usaha yang telah disusun, membangun usaha yang penuh inovasi baru secara kreatif sehingga dapat meningkatkan kualitas hidup, mengurangi pengangguran, serta mendukung majunya perekonomian. Kepada tim pelaksana, secara umum diharapkan dapat melanjutkan kembali kegiatan pengabdian ini dengan terjun secara langsung untuk membina para siswa yang memiliki semangat serta motivasi untuk membuka usaha sendiri/berwirausaha. Secara khusus diperlukan pelatihan lanjutan mengenai pembuatan/penyusunan analisis keuangan dalam rangka mendukung pembuatan perencanaan usaha dan pengembangan usaha. Perlu adanya kelanjutan pendampingan untuk mencoba membuka unit usaha kecil yang dikelola oleh para siswa sebagai inkubator bisnis di sekolah tersebut, sebagai wadah pelatihan wirausaha.

\section{DAFTAR PUSTAKA}

Alma, B. 2011. Kewirausahaan. CV Alfabeta. Bandung.

Bird, B. J. 1989. Entrepeneurial Behavior. Scott Foresman \& Co. United Kingdom.

Fregetto, E. 2005. Business plan or business simulation for entrepreneurship education?. 19th Annual National Conference Proceedings for the United
States Association for Small

Business and Entrepreneurship, Indian Wells CA.

Instruksi Presiden Nomor 4 Tahun 1995 tentang Gerakan Nasional

Memasyarakatkan dan Membudayakan Kewirausahaan (http://denawanto.com diakses pada 15 Febr 2018).

Intruksi Presiden Republik Indonesia. 1995. Peningkatan Peranan Wanita dalam Pembangunan di Daerah (http://peraturan.go.id/inpres/nomor-4tahun-1995 diakses pada 20 Februari 2018).

Jhingan, M.L. 1999. Ekonomi Pembangunan dan Perencanaan. Jakarta: Penerbit Rajawali Pers.

Peraturan Pemerintah No. 19 tahun 2005 Tentang Standar Nasional Pendidikan. Nugroho, R. 2009. Public Policy. PT Elek Media Komputindo. Jakarta.

Saiman, L. 2009. Kewirausahaan, Teori, Praktik dan Kasus-Kasus. Salemba Empat. Jakarta.

Subroto, W.T. 2013. Entrepreneurship development course to foster character merchandise in support economic growth. European Journal of Business and Innovation Research, 1 (1), 1-9.

Sumarsono, S. 2013. Kewirausahaan. Graha IImu. Yogyakarta.

Sumahamijaya, S. 1981. Membina Sikap Mental Wiraswasta. Gunung Jati, Jakarta.

UU No: 20 tahun 2003 tentang SISDIKNAS.

Winarto $\mathrm{V}$.

2003. Entrepreneurship: Semangat unt uk memberikan solusi bagai masyarakat (http//www.epsikologi.com/pengembangan/rls.htm, 30-01-2003)

Yohana, C. 2015. Pelatihan menyusun rencana usaha (business plan) bagi Pengusaha. 